\title{
Animasjon som multimodal analyse av fortelleruttrykk i barnehagen
}

\author{
Ingvild Olsen Olaussen * \\ Dronning Mauds Minne Høgskole for barnehagelererutdanning
}

\begin{abstract}
Sammendrag
Denne artikkelen er en metodisk refleksjon knyttet til en kunstnerisk tilnærming til forskning. I artikkelen undersøkes bevegelsen fra levd liv til fremstilling av forskningsresultat i en kvalitativ studie med en kunstnerisk tilnærming. Både skrevne narrativ og tegnede animasjoner er del av denne prosessen. Gjennom et slikt arbeid kan en kroppslig og sanselig forståelse av materialet vokse frem. Hensikten med artikkelen er å undersøke en kunstnerisk tilnærming gjennom en multimodal narrativ animasjonsanalyse. Datamaterialet er hentet fra delstudien "A playful orchestration narrative expressions by toddlers", hvor fortelleruttrykk av de yngste i barnehagen undersøkes. Prosessen er speilet giennom "den trefoldige mimesis» som Ricoeur har utviklet. Artikkelen løfter frem hvordan kunstnerisk medskaping gjennom animasjon av et fortelleruttrykk åpner for kompleksitet i fortelleruttrykket på en meningsskapende måte.
\end{abstract}

Nøkkelord: Metode; kunstnerisk forskning; narrativ; animasjon; kroppsfenomenologi

\begin{abstract}
This article is a reflection regarding method related to an artistic approach to research. The article examines the movement from lived life to the production of research results in a qualitative study based on an artistic approach. Both verbal research narratives and narrative animations are part of the inquiring process. Through the inquiry, a bodily understanding of the material can emerge. The purpose of the article is to investigate an artistic approach through a multimodal narrative animation analysis. The data is derived from the sub study «A playful orchestration - narrative expressions by toddlers", where narratives of the youngest in the kindergarten are explored. The process is reflected in the "threefold mimesis", which Ricoeur has developed and described in his main work Time and Narrative. The article makes visible, how an artistic approach through animation of a narrative expression opens up for the complexity of the expression in a meaningful way.
\end{abstract}

Keywords: Method; artistic approach; narrative; animation; body phenomenology

Received: June, 2017; Accepted: February, 2018; Published: March, 2018

\footnotetext{
^Korrespondanse: Ingvild Olsen Olaussen, Dronning Maud Minne Høgskole for barnehagelærerutdanning, Thrond Nergaards veg 7, N-7044 Trondheim. Epost: ioo@dmmh.no
} 
Figuren jeg har tegnet, kikker på meg fra papiret. Det er en liten gutt og han har fått en rød bil $i$ hånden, akkurat som gutten jeg observerte $i$ barnehagen. Feg knipser bilde for bilde, som fortløpende legger seg inn i stop-motion, mens jeg flytter papirhainden hans opp langs bakgrunnen. Feg har observasjonsnotatene ved siden av meg. Likevel må jeg innimellom lukke øynene for å forsøke à huske det som utspilte seg, som om jeg kan finne det der inne $i$ kroppen. Feg leter $i$ minnet etter stemningen, hvilke bevegelser han gjorde, tempo $i$ kroppen hans, ansiktsuttrykk og blikkbruk. Hvordan var uttrykket $i$ fortellingen han fortalte med den lille røde bilen? Bilde for bilde forsøker jeg à gi liv til papirgutten $i$ hendelsen som utspant seg.

(Narrativ basert på forskerlogg 18.09.15.)

I denne artikkelen undersøker jeg den metodiske tilnærmingen jeg har, i en undersøkelse av et barnehagebarns fortelleruttrykk i delstudien "A playful orchestration - narrative expressions by toddlers». Delstudien er en del av forskningsprosjektet Tilblivelsesfortellinger, fortelleruttrykk av og for de yngste $i$ barnehagen ${ }^{1}$, hvor fortelleruttrykk av de yngste $\mathrm{i}$ barnehagen undersøkes. Jeg tar utgangspunkt i datamaterialet fra det skapes gjennom deltagende observasjon, og undersøker de bevegelser jeg som forsker giør fra materialet analyseres i en multimodal narrativ animasjonsanalyse til det fremstilles som ferdig forskningsresultat. Jeg bruker begrepet bevegelse, som beskriver hvordan materialet som jeg skaper gjennom deltagende observasjon, gis nye former og uttrykk i løpet av forskningsprosessen, fra levd liv til fremstilling av forskningsresultat. De valgene og posisjonene jeg som forsker tar underveis, er med på å sette materialet i bevegelse mot min kroppslige forståelse og innsikt i barns ulike uttrykk i lek og fortelling. Disse valgene er metodologisk forankret i en kunstnerisk tilnærming til forskning (se Østern, 2017). Med en kunstnerisk tilnærming til forskning er jeg åpen for mulighetene som ligger i kunsten, og jeg anerkjenner hvordan blant annet det flersanselige kan åpne opp for flere betydningslag $i$ alle ledd av forskningsprosessen. Med bakgrunn som profesjonell forteller, opplever jeg at de prosessene jeg har med å finne et materiale å fortelle for et publikum, bearbeidelsen og senere fremføringen, har mange likhetstrekk med en kvalitativ forskningsprosess. Som forteller er dette blant annet for meg en kroppslig prosess hvor jeg fritt kan bruke mine sanser, mine og andres erfaringer og de estetiske virkemidlene jeg har for hånden. I spenningsfeltet mellom kunst og forskning finnes ulike betegnelser, befruktninger, betoninger og koblinger mellom kunst og forskning (Borgdorff, 2006, 2012). Med referanse til Barone og Eisner (2012) og Bresler (2006b), definerer Østern det å forske med kunsten som «en meningssøkende prosess der man aktivt tar i bruk ulike formspråk og modaliteter» (Østern, 2017, s. 5). I artikkelen reflekterer jeg over bruk av tegnede animasjoner og verbalt artikulerte observasjoner som en del av en multimodal, narrativ forskningsprosess. Dette metodiske grepet ble aktuelt tidlig i forskningsprosessen $\mathrm{i}$ "A playful orchestration - narrative expressions by toddlers». Gjennom arbeid med å transformere materialet fra skrevne observasjonsnotater til multimodale animasjoner, vokste den kroppslige og sanselige forståelsen av materialet frem.

${ }^{1}$ Den overordnede problemstillingen for hovedstudien er: Hva karakteriserer fortelleruttrykk av og for de yngste i barnehagen sett i et kunstnerisk utforskende multimodalt perspektiv? 


\section{O. Olaussen}

\section{Etiske overveielser}

Når jeg bearbeidet datamaterialet på denne måten, benyttet jeg min kompetanse som forteller i en kunstnerisk tilnærming, jeg skapte plotline, gjorde en dramaturgisk bearbeidelse, tegnet, malte og animerte. Slik dukket behovet opp for refleksjon omkring bruk av kunstneriske virkemidler som en del av prosessen. Forbindelsen til det levde liv er et premiss i forskning som medfører en etisk forpliktelse. Den norske forskningsetiske komiteen har utarbeidet retningslinjer for forskning innen ulike fagfelt. Her stilles blant annet krav til kvaliteten på dokumentasjonen som skal underbygge slutninger og konklusjoner i forskningen (Forskningsetisk komite, 2016). I kunstneriske prosesser er det krav om etterrettelighet i prosessen i forhold til de kunstneriske valgene som tas, og til bevissthet knyttet til etiske forpliktelser på individnivå. Når kunstneriske prosesser kobles med forskning, må imidlertid noe av den kunstneriske friheten vike plass. Kravene til kvaliteten på dokumentasjonen og kravet til transparens i forskningen er naturligvis et premiss også i forskning med kunstneriske tilnærminger.

\section{Hensikt og problemformulering}

Hensikten med denne artikkelen er å undersøke hvilke metodiske utfordringer og muligheter som oppstår ved bruk av animasjon sett som multimodal narrativ analyse. Problemformulering for artikkelen er: Hvilke metodiske utfordringer og muligheter oppstår ved bruk av multimodal narrativ animasjonsanalyse?

Som dialogpartner i diskusjonen brukes Paul Ricoeurs trefoldige mimesis (Ricoeur, 1984, s. 64), som er med på å utvide refleksjonene knyttet til de ulike fasene i prosessen.

\section{Kontekstualisering}

De første ukene jeg var i forskningsbarnehagen min, hadde jeg innhentet godkjenninger til å filme godt over halvparten av barna, men ventet fortsatt på klarsignal for resten. Ettersom jeg ikke kjente barna så godt, var jeg redd for å filme feil barn, noe som gjorde meg ufri i observasjonssituasjonen. Ut fra disse forholdene valgte jeg å gjøre løpende observasjoner uten kamera. En av de aller første observasjonene gjorde jeg sittende på gulvet med ryggen inn mot veggen og bena ut i rommet. Wilhelm², 2 år og 5 måneder, kom bort til meg og plasserte seg i fokus. Med en liten, rød bil i hånden og med tydelig nysgjerrighet nærmet han seg meg, denne fremmede damen som «plutselig» satt i barnehagen. Han kikket på meg mens han kjørte nærmere med bilen sin. Jeg forsøkte å se så nøytral ut som mulig der jeg satt (noe som også inkluderte et smil). Etter litt bilkjøring på gulvet kjørte Wilhelm bilen opp på meg, og benet mitt ble en del av den røde bilens ferd hvor kneets forhøyning utgjorde en

${ }^{2}$ Fiktivt navn. 
sentral hump i veien. Slik havnet jeg på orkesterplass til en fortelling som varte i ca. 18 minutter. Både plasseringen og det taktile i denne hendelsen er med på å understreke det kroppslige perspektivet i forskerens møte med feltet. Etter å ha vært i barnehagen og observert, dro jeg hjem og renskrev notatene fra observasjonen. Ut fra fokus i delstudien "A playful orchestration - narrative expressions by toddlers", ${ }^{3}$ opplevde jeg detaljnivået i transkripsjonene lite tilfredsstillende.

I arbeid med à undersøke det multimodale uttrykket $i$ observasjonen Wilhelm kjører bil, syntes det som et paradoks å skulle gjengi materialet kun som skrevne ord, den eneste modalitet som ikke er berørt $i$ observasjonen. Med bakgrunn $i$ denne erfaringen bestemte jeg meg for à gjøre et forsøk med à lage animasjon av observasjonen. I første omgang var dette eksperimentet ment som en kompensasjon for manglende videomateriale. I ønske om å anerkjenne og løfte opp et toddleruttrykk, stod video-observasjon frem som en helhetlig og mer kompleks, gjengivelse av materialet. Det plaget meg at flere av de observasjonsøktene som pekte seg ut som sentrale $i$ materialet var de der jeg deltok uten kamera. Arbeidet med selve animasjonen tvang imidlertid frem et annet perspektiv - det å se utformingen av animasjonen som en multimodal, narrativ analyse.

(Narrativ, basert på forskerlogg 18.09.15)

Det var altså i skjæringspunktet mellom materialet og problemformuleringen for delstudien at forsøket med animasjon som analyse dukket opp.

\section{Forskningsdeltagere og generert forskningsmateriale}

Materialet ble samlet inn høsten 2014 og våren 2015 i en barnehage på en småbarnsavdeling med 24 barn i alderen 1-3 år og med 8 voksne. Av disse hadde jeg innhentet godkjenning til observasjon, for 20 av barna. Observasjonene ble gjort etter hvilestunden midt på dagen. Materialet består av 10 observasjoner i form av feltnotater og løpende observasjon. I tillegg er det 33 sekvenser med videoobservasjoner av ulik lengde, hvor den korteste sekvensen er 48 sekunder og den lengste er på 16 minutter og 17 sekunder. Den sansende og meningsskapende kroppen er sentral i delstudien. Hensikten i delstudien, er å undersøke toddleres lekne fortellinger og se hvordan de prøver ut formuttrykk innenfor ulike modaliteter i en utforsking sentrert i en kroppslig tilstedeværelse.

\section{Metodisk bevegelse - fra levd liv til forskningstekst}

\section{Kroppsfenomenologisk plassering}

I delstudien, og i denne artikkelen, kan tilnærmingen karakteriseres som hermeneutisk-fenomenologisk. Som kropp er mennesker sansende og sansbare på én og samme tid, i en stadig sammenfletting mellom det levde livet og verden (Merleau-Ponty, 1968; Nortvedt, 2008). Med metaforen kiasme, sammenføyer Merleau-Ponty en materialitet som inkluderer våre kroppers materialitet med våre praksiser. Vi berører og blir berørt, og nettopp i bevegelsen mellom disse er vår egen subjektivitet lokalisert. «Tingene rører ved meg slik jeg rører ved dem og ved meg selv» (Merleau-Ponty, 1968, s. 261).

${ }^{3}$ Delstudien har et kunstnerisk utforskende multimodalt perspektiv. 


\section{O. Olaussen}

Vår bevissthet og våre opplevelser vil alltid være rotfestet i vår livsverden, en tilstedeværelse som er historisk, kulturell og sosial (Bengtsson \& Løkken, 2004, s. 565). Kroppen er sansende, persiperende, handlende, følende og talende. Kroppen er «et knudepunkt af levende betydning», skriver Merleau-Ponty (1994, s.109) og sammenligner kroppen med et kunstverk. Dette knutepunktet av levende betydning finner stadig nye forbindelser i møte med seg selv og verden. Slik forstås subjektet som noe som både er og blir til. De sanselige erfaringer og mønstre kroppen bærer med seg, er ikke statiske. Det er erfaringer og sansninger i tid, men formuleringen «levende betydning» peker på det dynamiske hvor verden slik den kommer oss i møte i øyeblikket, og det sanselige materialet vi bærer med oss, fritt kan spille sammen og finne nye meningsforbindelser.

\section{Den trefoldige mimesis - metodisk bevegelse}

Prosessen fra levd liv, slik jeg observerte det i forskningsbarnehagen, til fremstilling av forskningsresultat, har jeg speilet med «den trefoldige mimesis» som Ricoeur har utviklet og som han gjør rede for i sitt hovedverk Time and Narrative I (Ricoeur, 1984, s. 64). I beskrivelsen av den trefoldige mimesis synliggjøres tre ulike faser ${ }^{4}$ av en prosess. Ricoeur løfter frem hvordan bevegelsen mellom tre faser, med benevnelsen figurasjoner, mimesis 1 - forfigurasjonen, mimesis 2 - konfigurasjonen og mimesis 3 - omfigurasjonen, innebærer en nyformulering av mening. Figurasjonene beskriver de forandringer som skjer med materialet i denne delstudien. I de ulike fasene av figurasjonen, eksisterer og oppstår nye forbindelser i materialitetene i levd liv. I bevegelsen fra den ene fasen til den andre løser forbindelsene seg og finner nye koblinger. Materialet omgrupperer seg, det løser seg opp og antar nye former,

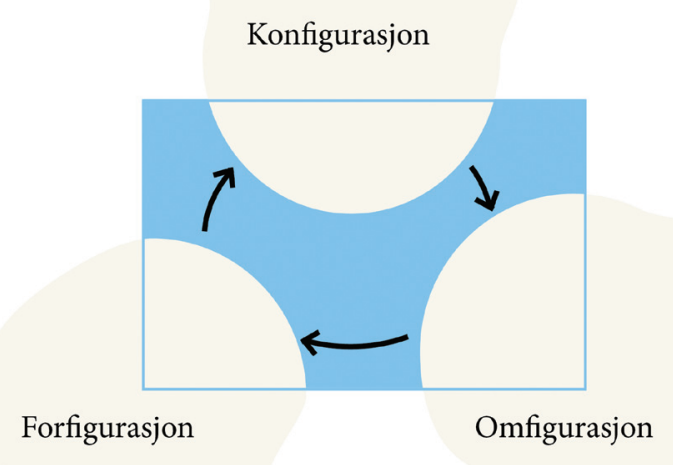

1. SEKVENS

Figur 1. Trefoldige mimesis.

${ }^{4}$ Tre ulike faser i tid. 
i stadig nye tilblivelser. Her synliggjør jeg hvordan jeg som forsker går inn i ulike faser eller posisjoner og skaper ny mening. Dette er visualisert i en modell, se figur 1. Forfigurasjonen er 1. mimesis, konfigurasjonen 2. mimesis og omfigurasjonen er 3. mimesis.

Med figur 1 forsøker jeg å synliggiøre hvordan livet alltid er mer mangfoldig og komplekst enn det som lar seg fange i en tekst. Prosessen gjentar seg i stadig nye sekvenser. Kunstbasert forskning, og kunstnerisk tilnærming til forskning, åpner for at forskersubjektet $\mathrm{i}$ alle faser av prosessen, også i analysen, spiller på de muligheter som finnes innenfor et mangfoldig uttrykksrepertoar.

\section{Mimesis 1: Deltagende observasjon - det levde liv}

Den første posisjonen jeg tar i prosessen, er som deltagende observatør. Her møter forskeren feltet og skaper sitt materiale. Det er mine kroppslige, sanselige møter i barnehagen som er utgangspunktet for generering av materialet. Disse hendelsene er karakterisert som levd liv, det Merleau-Ponty kaller levende betydning. Ricoeur betegner det levde livet som forfigurasjonen (se figur 1). Det levde liv forstår jeg som våre handlinger og sansede opplevelser som utgjør alle menneskers tilgang til verden og muligheten til å oppfatte tid. «...the composition of the plot is grounded in a preunderstanding of the world of action, its meaningful structures, its symbolic resources, and its temporal character» (Ricoeur, 1984, s. 54). Evnen til å strukturere et plot hviler nettopp på forfigurasjonen. Uten denne sansemessige kontakt med verden, med både lidelse og glede, ville mennesket ikke være i stand til å strukturere fortellinger.

Det opplevede og erfarte utgiør forforstålsen for den omstrukturering som kommer med mimesis 2, en omstrukturering av levd liv, som skaper nye meninger. Observasjonen er sterkt forbundet med forskersubjektet, med dennes kropp, sanser og sensitivitet. Øyeblikket som observeres, kommer ikke tilbake og kan ikke oppleves annet enn i observatørens gjengivelse av hendelsen. Hendelsen fikseres i en fremstilling, og all den tid vi ikke kan reise i tilbake i tid og faktisk oppleve, må vi nøye oss med gjengivelsen. Det kan ikke sies å være et distinkt skille mellom observasjonen og analysen. Analysen starter allerede i observasjonen. De fleste har kanskje opplevd å formidle noe selvopplevd med selvsikkerhet og innlevelse, og i det fortellingen når sitt klimaks, bryter noen (en mor, en ektefelle) inn og sier, «Nei, det var ikke slik det var!» Selv om vi har opplevd den samme hendelsen, kan forståelsen av hva som fant sted, variere fra person til person. Hvilke perspektiv vi vektlegger og hvordan vi skriver ned det vi observerer, henger sammen med hvem vi er i møte med hendelsen. Observasjonene vi legger til grunn er subjektive opplevelser, følgelig vil de narrativ som skapes på bakgrunn av dette materialet, være preget av min uttrykksform. Handlingen fikseres i det den festes til papiret og skrives ned. I det samme løsrives den både fra opprinnelig tid og sted.

Gudmundsdóttir (2011, s.50) skriver:

Når den fikseres, får den formidlede handlingen sin egen autonomi. Handlingen og dens mening er frigjort fra tidspunktet, begivenheten og personen og har fått selvstendig betydning. De setter spor i det sosiale rom og blir 'dokumenter om menneskelig handling' i det kollektive minne. 


\section{O. Olaussen}

I det handlingen løsrives fra tiden, er det noe som går tapt. Blant annet koblingen til den personen som utførte handlingen og dennes erfaringer og historie. Da blir det nødvendig å spørre seg hva av det omkringliggende det er vesentlig å si noe om.

\section{Mimesis 2: Analyse - et mulighetenes rom}

I Mimesis 2, åpnes et mulighetenes rom. "With mimesis 2 opens the kingdom of the as if (Ricoeur, 1984, s. 64). Uttrykket Ricoeur har valgt, kan oversettes til kongeriket som om, hvor betegnelsen som om henspiller både på en utforsking som kan utspille seg innenfor en kunstnerisk praksis, imaginasjonen og lekens aktivitet. Idet man trer inn i kongeriket som om, åpner mulighetene seg for oss. På bakgrunn av det levde liv, den kroppslige tilstedeværelse og sansenes erfaringer av verden åpner muligheten seg for å skape noe, noe nytt. Det sanselige materialet omgrupperes i en mulig verden en konfigurasjon, et kunstverk, en fortelling, som også kan sees som en form for analyse, hvor erfaringer og sanseinntrykk settes sammen på en ny måte. De nye konstellasjonene gir nye meninger og åpner andre rom.

Narrativ metode tar utgangspunkt i menneskets evne til nettopp å strukturere opplevelser i form av en fortelling. Det opplevede og erfarte utgiør forforståelsen for en omstrukturering av opplevd liv, der det skapes nye meningsforbindelser (Ricoeur, 1984, s. 64). Uten den sansemessige erfaringen av verden ville vi ikke besitte et materiale å skape nye fortellinger ut fra. Denne bundethet til «virkeligheten» giennom observasjon og i menneskets sansemessige erfaringer, er noe som også gir mulighet til at analysen kan mottas og finne feste i nye betydninger.

Analysen trekker øyeblikket fra observasjonen enda lenger vekk fra dens opprinnelige sammenheng. Samtidig åpnes det opp for at øyeblikket finner nye meningsforbindelser og betydninger i møte med nye fortolkningsrammer. Gudmundsdóttir (2011, s. 50) formulerer seg slik om dette: «Episoden er frigjort fra sin opprinnelige diskurs og kan nå inngå i nye fortolkningsrammer hvor den kan anta nye betydninger som ikke var tilsiktet av vedkommende som var involvert i den opprinnelige handlingen.» Det er etiske implikasjoner forbundet med å bruke andres erfaringer og opplevelser. Fremstilling av andre menneskers handlinger og disses betydninger, medfører et stort ansvar for forskeren. I mitt tilfelle er det snakk om små barn, og selv om handlingene ikke er av sensitiv karakter, er det foreldrene og ikke barna selv som gir samtykke til at hendelsene kan benyttes. Vurderingene som giøres underveis i forhold til hva som er etisk forsvarlig når personvern, menneskeverd og hensyn til forskningsdeltageren skal overveies, er forskerens ansvar og noe som krever en stadig årvåkenhet.

\section{Multimodal narrativ analyse}

Det ligger rike muligheter i analysen. Når i tillegg fokuset i analysen er det multimodale hvor forståelsen av hva teksten er, utvides til å gjelde ikke bare det skrevne og verbalartikulerte, men også det audiovisuelle, visuelle, fysisk signatur, samt taktile og spatiale modaliteter, åpner det seg flere felt med mange lag og rike muligheter. I multimodal analyse er fokus å kartlegge hvordan multimodale ressurser 
brukes av mennesker i en gitt sosial sammenheng, med andre ord tegnskaping som en sosial prosess (Jewitt, 2011, s. 30). Innenfor hver av modalitetene skjuler det seg store kunst- og kunnskapsfelt, med lang historie, rike tradisjoner, teknikker, materialer og strategier utviklet gjennom hele menneskehetens historie. Herunder ligger også kunstneriske tilnærminger. Med det store mulighetsrommet som åpner seg i en kunstnerisk tilnærming, blir en viktig markør for forskeren hvordan en kan redegjøre både for kunstneriske valg og de valg som er gjort underveis sett i forskningsetisk og samfunnsmessig perspektiv. Disse perspektivene er knyttet til transparens i prosessen.

\section{Mimesis 3: Omfigurasjonen - tilbakeføring til det levde liv}

I Mimesis 3 fullføres fortellingen i møte med leserens verden. Her møter analysen leseren og dennes sanselige tilstedeværelse i verden. Leserens erfaringsbakgrunn aktiveres i møte med teksten. Ricoeur betegner dette som omfigurering av fortellingen i leserens verden (Ricoeur, 1984, s. 71). Ringen sluttes altså i denne tredje fase i omfigurasjonen, hvor analysen fullføres, i dette tilfellet, i møte med teori. Det hele er iscenesatt av forskeren, jeg, som 'leser' og dermed medskaper. Når fortellingen plasseres inn i en ny kontekst, skjer det en omfigurering av fortellingen. Fortellingen blir til på nytt i møte med den diskursen det settes inn i. Gudmundsdóttir (2011, s. 50) beskriver denne tilblivelsen slik:

På samme måte som en tekst, er menneskelig handling et åpent verk hvis mening svever i 'det uvisse'. Fordi teksten 'åpner opp for' nye referanser og får ny relevans fra dem, venter også menneskelige handlinger på nye fortolkninger som bestemmer deres betydning.

Her berøres også noe av ansvaret forskeren har som iscenesetter av tekst hvor betydning av andre menneskers handlinger bestemmes av fortolkningen som giøres. Fortellingens flyktighet er et perspektiv som kan være viktig å være oppmerksom på i møte med narrativ analyse. Vi er i stadig forandring, våre perspektiv og våre hensikter er i bevegelse, følgelig vil vårt møte med fortellinger forandre seg, slik Bresler (2006a, s. 26) skriver:

Even when shared in honesty, narratives are, by definition, selective, reflecting our own perceptions, which are ever-changing as we change. It is with a sense of this ephemeral quality that we should treat them, recognizing that they can be powerfully illuminating, but are not to be confused with the Truth that postmodernism acknowledged as impossible.

Igjen er forskerens bevissthet og årvåkenhet sentral i behandlingen av og i møte med narrativ. Så når jeg i omfigurasjonen setter narrativet og animasjonen inn i en teoretisk sammenheng, settes de igjen i bevegelse, bort fra det de en gang var og blir noe nytt.

Disse tre posisjonene står $\mathrm{i}$ et tett innbyrdes forhold til hverandre. Mimesis 2, konfigurasjonen forutsetter mimesis 1 - forfigurasjonen for å skape struktur, men forfigurasjonen er allerede strukturert i og med at den er et resultat av mimesis 3omfigurasjonen. I omfigureringen av fortellingen, mimesis 3, kommer tilhøreren frem til en ny eller utvidet forståelse av fortellingen, og på den måten også av verden. 


\section{O. Olaussen}

Denne nye tilstanden og forståelsen vil danne den neste forfigurasjon, og så videre. Bevegelsen mellom de ulike posisjonene er en kontinuerlig og dynamisk prosess. Det er en prosess for å skape mening og for å forstå, en prosess hvor hver posisjon henger sammen med og er avhengig av de andre posisjonene.

\section{Materialet settes i bevegelse}

I det videre vil jeg utdype bevegelsen mellom de ulike posisjonene jeg har forsøkt å introdusere, med materialet fra "A playful orchestration - narrative expressions by toddlers». Gjennom å fokusere på analysen (Mimesis 2), ønsker jeg å synliggiøre muligheter og utfordringer som oppstår ved bruk av multimodal narrativ analyse.

\section{Wilhelm og bilen}

I kontekstualiseringen innledningsvis i denne teksten synliggiør jeg hvordan observasjonen av Wilhelm også er et kroppslig møte med barnehagen. Jeg sitter på gulvet med ryggen inn mot veggen og bena ut i rommet. Bilkjøringen jeg observerer, foregår delvis på benet mitt, og jeg kan kjenne de små bilhjulene over kneet. Hendelsen understreker det kroppslige perspektivet i forskerens møte med feltet. Notatene jeg har gjort, gjenspeiler observatørens møte med Wilhelms bilkjøring.

Wilhelm forteller en historie om en bil. Rent verbalt lyder fortellingen omtrent slik: Au, au, au jeg faller. Nå, ble han trott, nå måtte han sove. Han krasjet med romskip. Han er kjempetrøtt og må sove. Utvides gjenfortellingen av Wilhelms historie slik at den inkluderer handlinger og lyder, forandrer fortellingen seg og blir langt rikere. I denne observasjonen fra barnehagen forteller Wilhelm i 18 minutter om bilen og dens ferd. Fortellingen har en god oppbygning og er sammensatt av bevegelse, lyd, ord og meningsfulle handlinger. Gjennom fortellingen synliggiør Wilhelm en mangfoldig kompetanse uttrykt $i$ et rikt tegnlandskap. Wilhelm musiserer, dramatiserer og forteller.

Som jeg skrev tidligere, opplevde jeg detaljnivået i transkripsjonene lite tilfredsstillende med tanke på at jeg ville undersøke denne bilfortellingen $i$ et multimodalt perspektiv. I notatene fra observasjonene hadde jeg naturlig nok bare klart å skrive ned deler av det jeg hadde observert. For å kompensere for manglende videomateriale forsøkte jeg å lage en tegnet animasjon av observasjonen. I selve arbeidet med animasjonen vokste en forståelse frem av at animasjonene ikke var utvidede observasjonsnotater, men kunne sees som en analyse. Dette er knyttet blant annet til den kroppslige bevisstgjøringen det ga å arbeide med animasjonen. Hvis jeg hadde planlagt å bruke animasjon som en del av analysen før jeg observerte, er det nærliggende å tro at den kroppslige tilstedeværelsen i observasjonen ville ha vært ytterligere skjerpet.

Analyse - skapende uttrykk i multimodal narrativ analyse

I narrativ multimodal analyse setter forskeren sitt preg på fremstillingen i et skapende uttrykk. Forskeren setter sin signatur på uttrykket uansett hvilken form 
det arbeides innenfor, om det er skreven tekst, om det danses, eller dramatiseres. Enhver som har forsøkt å iscenesette et manus, vet at regissørens valg tydelig kommer til uttrykk i det sceniske uttrykket. Regissørens fokus og tolkning blir gjennom arbeidet med tekst og skuespiller en del av det endelige uttrykket. I hendelsen med den røde bilen er det Wilhelm som er forteller, formgiver eller tekstforfatter, men det er jeg, forskeren, som noterer det han sier og giør. Allerede i observasjonen gjør jeg valg basert på mine perspektiv og min forståelse av hendelsen. I arbeid med analysen transformerer jeg observasjonsmaterialet til et nytt uttrykk. I arbeid med animasjon er omdreiningspunktet samspillet mellom materialet det arbeides i og animatøren. Hamre skriver at animasjonskunst tar utgangspunkt $i$ at gjenstanden som skal animeres, har en kjerne, at den bærer en hemmelighet som den skal få bevare (Hamre, 1997, s. 30). I arbeid med å animere forsøker animatøren å hente ut det Hamre karakteriserer som figurens kjerne, eller indre dynamikk, med hensikt å gi figuren liv. Det er et samspill hvor animatør og figur spiller sine kvaliteter opp mot hverandre (Olaussen, 2015, s. 119). I arbeidet med animasjonen har jeg en dialog med figuren som skal animeres, en dialog hvor jeg er intenst fokusert på figuren.

I utformingen av Wilhelms bilfortelling var spørsmålet hva som var viktig å få frem. Dette måtte sees i lys av analyseenhetene i studien. Analyseenhetene måtte stå i forhold til problemformuleringen for studien. Analyseenhetene er de tematikker, modaliteter og virkemidler det spilles på i uttrykket. På bakgrunn av observasjonsnotatene, sett i lys av kategoriene (se matrise 1), er den tydeligste trenden i narrativet den røde bilen, forsøkt forsterket. Dette har jeg gjort både i en 19 sekunders animasjon og i et skriftlig uttrykk. Det er to ulike uttrykk som begge kan sees som en analyse av materialet.

\section{Matrise - de ulike modalitetene Wilhelm spiller på}

I arbeidet med klargjøring av materialet laget jeg en matrise som skulle gi en systematisk oversikt over de ulike modaliteter som barna spilte på i sine fortellinger. Matrisen er inspirert av Cope og Kalantzis (2009) som foreslår åtte modaliteter: en spatial, knyttet til romlige forhold, en fysisk signatur, taktil, muntlig, audiovisuell, visuell og skreven modalitet. De foreslår også en indre modalitet, som jeg har valgt bort. Kiasmen er en metafor som ikke henviser til det indre og det ytre. En kroppsfenomenologisk tenkning forstår mennesket som et kroppssubjekt og kiasmen som en dekkende metafor for å røre ved og bli berørt (Merleau-Ponty, 1968; Nortvedt, 2008). Cope og Kalantzis indre modalitet blir ikke aktuell i denne sammenhengen da alle modalitetene spilles ut i sammenflettingen mellom å røre ved og bli berørt. Ut fra bevisstheten som vokste frem i arbeidet med matrisen (se matrise.1), formulerte jeg et skriftlig narrativ. Med bakgrunn i narrativet og matrisen ble hendelsene transformert til små animasjoner hvor de ulike modalitetene ble «malt ut.» Med kiasmemetaforen sammenføyer Merleau-Ponty våre kroppers materialitet med våre praksiser, $i$ en stadig sammenfletting mellom det levde livet 


\section{O. Olaussen}

og verden. Matrisen synliggjør både barnas praksiser og kroppslige materialitet uten at den makter å "gripe» subjektet.

\begin{tabular}{|c|c|}
\hline $\begin{array}{l}\text { Observasjon } 01.2 \\
\text { Wilhelm, } 2 \text { år og } 5 \text { mnd. }\end{array}$ & $\begin{array}{l}\text { Observasjonens lengde: } 18 \text { minutter } \\
\text { Tittel: «Wilhelm kjører bil» }\end{array}$ \\
\hline Spatial modalitet & $\begin{array}{l}\text { Bilens ferd i det fysiske rommet: På benet mitt, på gulvet ved siden } \\
\text { av meg, i luften og noen meter unna på en stor grønn pute. }\end{array}$ \\
\hline Fysisk signatur & $\begin{array}{l}\text { Lever seg inn i rollen som bil. Notert: Jeg rakk ikke å notere } \\
\text { ansiktsuttrykk og uttrykk for innlevelse, som når bilen slo seg og } \\
\text { når den var trøtt, men her var det utforsking av et rikt repertoar. }\end{array}$ \\
\hline Taktil modalitet & $\begin{array}{l}\text { Kontakt mellom hånd og bil. Kontakt med underlaget. } \\
\text { Ulike underlag: Ben, gulv, grønn pute, luft. }\end{array}$ \\
\hline Muntlig modalitet & $\begin{array}{l}\text { "Au, au, au, jeg faller. Nå ble bilen trøtt og må sove.» Små-snakking } \\
\text { under bilkjøring som jeg ikke hører. }\end{array}$ \\
\hline Audiovisuell modalitet & $\begin{array}{l}\text { Ulike kjørelyder som: Øøøøøørn, brrrrrr, tut, bang, bæng, etc. Fikk } \\
\text { ikke med alle variasjonene. Fremført med ulik intensitet, variasjon i } \\
\text { tempo, klang og styrke. }\end{array}$ \\
\hline Visuell modalitet & $\begin{array}{l}\text { Bilen er fortellingens omdreiningspunkt og den sentrale artefakt. } \\
\text { Mitt kne, gulvet og den grønne puta utgjør en scene for bilens ferd. }\end{array}$ \\
\hline Skreven modalitet & Ikke relevant for denne observasjonen. \\
\hline
\end{tabular}

Matrise 1. Ulike modaliteter i bruk.

\section{Skriftlig artikulert narrativ - den røde bilen}

Det første jeg gjorde var å skape et narrativ i den modaliteten som observasjonen av Wilhelm forelå i, den skrevne modaliteten. Selv om oppbygningen av bilkjøringen var notert med skrevne ord som indikerer tempo, rytme, pauser og brudd, var ikke dette gjort med for eksempel musikalske notasjoner som kanskje ville ytt bilkjøreren større rettferdighet. I notatene hadde jeg skrevet "Bilen øker farten» Bilen har en replikk, "au, au, jeg faller,» (sagt med dramatisk stemme). En kunne vurdere, ettersom disse lydene er sentrale, å lage et narrativ som inkluderte en slik musikalsk notasjon over bil-lyder.

Når jeg skulle utforme et narrativ gikk jeg først tilbake til notatene jeg hadde gjort ute $i$ feltet og leste gjennom disse. Her støtte jeg på en utfordring. Når jeg leste notatene fikk jeg en kroppslig opplevelse av den beskrevne hendelsen som gikk ut over de ordene som er notert. feg mente også å huske nye moment når jeg leste det jeg selv hadde skrevet. Det var vanskelig à avgjøre hvorvidt det som dukket opp var noe som faktisk skjedde $i$ den observerte sekvensen eller om dette var erfaringer og minner jeg hadde fra andre opplevelser som jeg leste inn $i$ den gjeldende observasjonen. Feg gjorde et valg om ikke å inkludere de nye momentene, men holde meg til det jeg hadde notert i observasjonene. Når det gjaldt den kroppslige opplevelsen ordene ga, valgte jeg å la dette få plass. Notatene jeg hadde skrevet 
for å huske situasjonen, var i en svart konsentrert og knapp form. Når jeg skulle analysere situasjonen, måtte jeg la ordene løse seg opp $i$ situasjonen.

(Narrativ, basert på forskerlogg 18.09.15)

I utformingen forsøkte jeg å inkludere deler av det omkringliggende slik at den konteksten hendelsen utspilte seg i, ble en del av narrativet. Det er ganske stille i barnehagen, de aller fleste barna sover. Fem barn har allerede våknet og er i gang med lek. Wilhelm har funnet seg en liten rød bil. Han begynner å kjøre omkring på gulvet med bilen. Blikket er svært konsentrert og festet på den lille røde. En lav brummelyd akkompagnerer bilens ferd. Wilhelm er så konsentrert om kjøringen at han nesten går $i$ ett med bilen. Det er ikke helt godt å si hvorWilhelm slutter og bilen begynner. Med blikket festet på meg kjører han bilen opp på benet mitt.

\begin{abstract}
Bilen akselererer, farten øker og lyden som følger intensiveres fra en lav brumming til intens bil-dur. Fortere, fortere og fortere, så dabber det av til bilen så vidt beveger seg fremover. Den stopper ikke, den snegler seg fremover $i$ lusefart. Så plutselig nesten hoster bilen og gjør et hopp fremover og det er på igjen. Bilen fyker av sted som en pil, skyter fremover og lyden som følger ligner mest lyden av et fly. Det tar ikke lang tid før bilen letter fra bakken, hjulene finner feste i løse lufta og suser av gårde. Bilen flyr. Den kjører ut $i$ verdensrommet. Bilen kjører mellom stjerner og planeter der oppe, $i$ sakte svev og raske byks, men med ett blir den lille rød fryktelig sliten og må hjem for å hvile $i$ senga. Hvilestunden blir ikke lang før teppet kastes til side, bilen gjør et hopp og er i gang igjen. Enda en gang farer bilen av sted, det er «bånn gass» ut $i$ rommet. Der ute svever den rundt og utforsker farten, helt til den krasjer med et romskip. Bilen spinner rundt, virvler ned mot bakken, så flater den helt ut.
\end{abstract}

(Narrativ, på bakgrunn av observasjon 07.01.15)

\title{
Animert narrativ - den røde bilen
}

I forsøket på å gjenskape det multimodale uttrykket i observasjonene, syntes animasjon å være et ganske dekkende uttrykk. Den første observasjonen som ble transformert til animasjon, var Wilhelms bilkjøring, som varer i 18 minutter. Bare det å lage 19 sekunder med animasjon tar svært lang tid. Å lage så mye som 18 minutter med animasjon, ville være svært tidkrevende. Tanken om å se animasjonen som en reduksjon og en fortetning av observasjonen, dukket opp. I det valget ligger en forståelse av animasjonen som en form for analyse som spiller på lag med det materialet som skulle analyseres. Etter hvert ga jeg animasjonen status som multimodal narrativ analyse, snarere enn multimodal transkripsjon av observasjonen. I animasjonen synliggjør jeg det jeg har vektlagt som sentrale moment i observasjonen. Selv om animasjonen ikke er lang, har den mange lag hvor de ulike komponentene spiller sammen. I arbeidet med animasjonen opplevde jeg i stor grad hvordan både mitt uttrykk og min kroppslige tilnærming fikk spille inn $\mathrm{i}$ analysen.

I det animerte narrativet har jeg tegnet Wilhelm, som er den sentrale aktøren og fortelleren av bilfortellingen. Videre har jeg tegnet den røde bilen som har den bærende rollen i fortellingen. 


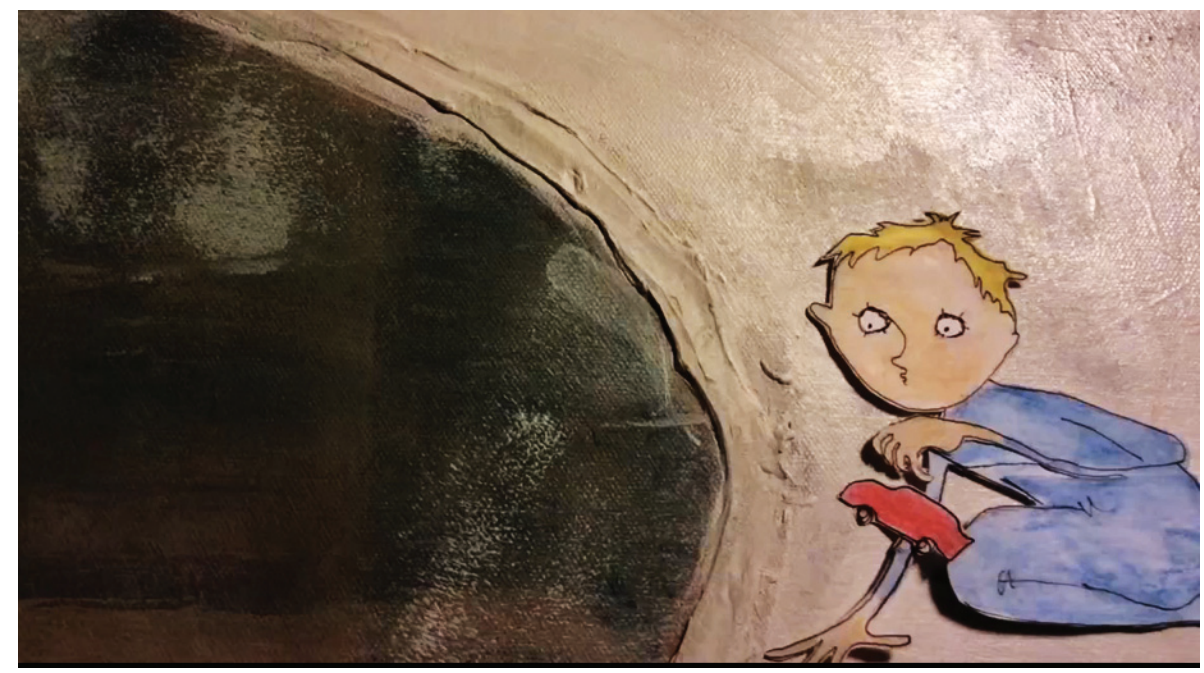

Figur 2: Den røde bilen, utsnitt fra animasjon.

Som observatør har jeg en opplevelse av at Wilhelm og bilen er ett. I animasjonen forlater bilen Wilhelms hånd og kjører ut $\mathrm{i}$ verdensrommet, her blir vi med inn $\mathrm{i}$ fortellingen som Wilhelm skaper. Lengden på bilens ferd er ikke foldet ut i det animerte narrativet, derimot har jeg tegnet ett av spenningspunktene i fortellingen, nemlig der bilen treffer og krasjer med romskipet. Hendelsen spiller seg ut i tid og rom gjennom at Wilhelm kjører bilen gjennom luften og treffer et imaginært romskip. Animasjonen er å finne hvis man klikker på denne hyperlenken: https://vimeo.com/167405224

Der den skriftlig artikulerte fremstillingen kanskje kan gi inntrykk av å være gjengivelsen av det som «faktisk» skjedde, markerer den lille animerte sekvensen tydeligere at dette er et skapt uttrykk. En kan undre seg over om nettopp denne markeringen skaper en god distanse mellom materialet og analysen. Et rom som skaper en positiv spenning. Gjennom arbeidet med å transformere materialet over til en annen modalitet ble fokuset på det kroppslige i uttrykket forsterket. Materialene som papiret og fargene jeg arbeidet med, brakte med seg muligheter og materialitet inn i arbeidet. Dette arbeidet gav en annen forståelse av materialet, og det bidro med en annen forståelse av analysen. "...human reality is shaped by patterns of bodily movement» (Flewitt, Hampel, Hauck \& Lancaster, 2011, s.42). Gjennom å forsøke å sette seg inn i det kroppslige mønsteret som skulle undersøkes for å få til de ønskede bevegelsene av figurene i det animerte narrativet, oppstod en ny og mer kompleks relasjon til materialet. «Sanser og bevidsthet er aktiveret i en fælles koncentration om bevægelser, dær lægges helt utenfor kroppen» (Hamre, 1997, s. 45). Oppmerksomheten var, selv om jeg brukte mine kroppslige erfaringer, fullt og helt på figuren som skulle animeres, i noe som minnet om en tilnærmet meditativ prosess. Her er det valg som er sterkt preget av min kroppslige opplevelse av verden, min puls, rytme og mine kroppslige erfaringer i verden. Uttrykket $i$ analysen blir, slik jeg ser det, enda tydeligere farget av meg og bærer min signatur. 


\section{Betydningen av en kunstnerisk tilnærming gjennom animasjon som multimodal analyse}

I dette arbeidet var de ulike narrative uttrykkene, det skriftlige og det animerte, med på å utfylle analysen på hver sin måte. Det skrevne narrativet kommuniserer tydeligere den settingen hendelsen foregår i og peker konkret på kontakten mellom Wilhelm og observatøren. Det animerte narrativet får tydeligere frem det kroppslige og poetiske $i$ hendelsen og formidler i større grad en stemning nettopp fordi flere modaliteter tilbyr meningsinnhold i flere lag. De to ulike narrative uttrykksformene jeg benytter meg av, har enorme potensialer, hvor jeg i denne sammenhengen bare har benyttet en liten del. Slik de er brukt i denne studien, spiller de to ulike uttrykkene sammen og kompletterer hverandre. Noe av det som trer tydelig frem, er hvordan de ulike analysene baserer seg på en struktur der forskeren er med på å prege uttrykket som skapes i analysen. På ulike vis kommuniserer de sitt meningsinnhold i en tekst som er formgitt av en subjektposisjon. En slik innrømmelse kan være med på å dempe uroen som oppstår i mine fremstillinger av barnas meningsskaping, der jeg til tider kan kjenne uro for at jeg tar for stor plass som forsker.

I animering av Wilhelm og hendelsen som utspiller seg med den røde bilen, vendes forskerens oppmerksomhet og konsentrasjon mot materialet gjennom en sanselig og kroppslig tilnærming. Gjennom ulike kunstneriske formspråk analyseres Wilhelms bilfortelling i et uttrykk som spiller på lag med hans eget fortelleruttrykk. I artikkelen argumenterer jeg for at Ricoeurs trefoldige mimesis gir en god speiling av de metodiske bevegelser som oppstår ved en kunstnerisk tilnærming til forskning. Gjennom de muligheter som åpner seg i analysens mulighetsrom, kan kunstneriske uttrykk utfolde seg. Et forhold som er svært fremtredende i Ricoeurs trefoldige mimesis, er nettopp hvordan de tre posisjonene er uløselig knyttet sammen. Her slippes aldri tanken om at analysen, så flyktig eller skapt den enn kan fremstå, er forbundet med levd liv, gjennom både observasjon og formidling. Her skiller kunsten lag med forskningen. I en kunstnerisk prosess hvor jeg har skapt fortellinger i ulike materialer og uttrykk, er kravet til etterrettelighet i prosessen av en annen karakter. Behovet for transparens og etterrettelighet er vesentlig i forskningssammenheng og kan selvfølgelig også være det i mang en kunstnerisk prosess. Hvis bundetheten til materialet ikke er der, kan en spørre seg om det har gått over til å bli noe annet enn en analyse. På samme måte som at "as if» - "som om», slik vi finner det hos Ricoeur, kan forstås som et premiss og ikke en mulighet $i$ analysen, kan forbindelsen til mimesis 1 , og mimesis 3 sees som et premiss og ikke en mulighet $i$ forskning med kunstneriske tilnærminger. Slik er disse uløselig knyttet sammen i en prosess for å skape mening. Denne forbindelsen er et premiss i forskning, også når en forsker med kunsten. Gjennom en slik argumentasjon vil artikkelen løfte frem mulighetsrommet som finnes i analysen. Samtidig løftes de perspektiv frem som synliggjør hvordan en også i kunstneriske tilnærminger til forskning må være seg bevisst forbindelsen til det levde liv, og de forskningsetiske forpliktelser det medfører. 


\section{O. Olaussen}

\section{Forfatterpresentasjon:}

Ingvild Olsen Olaussen er høyskolelektor og ph.d.-stipendiat i drama og teater ved Dronning Mauds Minne Høyskole. Hun er opptatt av muntlig fortelling, multimodale perspektiv og kunstfaglige innganger til læring, lek og forskning. Hun har siden 1996 arbeidet som forteller og har bred erfaring som utøver fra skole, barnehage, bibliotek, teater og ulike kulturinstitusjoner. Hun har gjennomført flere kunst- og forskningsprosjekter hvor barns praktisk skapende arbeid har stått sentralt.

Siden høsten 2014 har hun arbeidet med ph.d.- prosjektet Tilblivelsesfortellinger, fortellinger av og for de yngste i barnehagen sett i et multimodalt perspektiv. Gjennom dette prosjektet utforskes ulike former for

fortelleruttrykk og meningsforhandling av og mellom de yngste barna og en forteller.

\section{Referanser}

Barone, T. \& Eisner, E. (2012). Arts Based Research. Thousand Oaks, California: SAGE.

Bengtsson, J. og Løkken, G. (2004). Maurice Merleau-Ponty: Kroppens verdslighet og verdens kroppslighet. I K. Steinsholt \& L. Løvlie (Red.), Pedagogikkens mange ansikter. Pedagogisk idéhistorie fra antikken til det postmoderne (s. 555-570). Oslo: Universitetsforlaget.

Borgdorff, H. (2006). The debate on research in the arts (Vol. no. 02). Bergen: Kunsthøgskolen i Bergen.

Borgdorff, H. (2012). The conflict of the Faculties. Perspectives on Artistic Research and Academia. Leiden: Leiden University Press.

Bresler, L. (2006a). Embodied Narrative Inquiry: A Methodology of connection. Research Studies in Music Education, 27, 21-43.

Bresler, L. (2006b). Toward Connectedness: Aesthetically Based Research and its Ethical Implications. Studies of Art Education. A fournal of Issues and Research 2006, 48 (1), 15.

Cope, B. \& Kalantzis, M. (2009). «Multiliteracies»: New Literacies, New Learning, Pedagogies: An International fournal, 4:3, 164-195.

Flewitt, R., Hampel, R., Hauck, M. \& Lancaster, L. (2011). What are multimodal data and transcription? I C. Jewitt (Red.), The Routledge Handbook of Multimodal Analysis (s. 40-53). New York: Routledge.

Forskningsetisk komite. (2016). Forskningsetiske retningslinjer for samfunnsvitenskap, humaniora og juss. Hentet 27.04.17 fra, https://www.etikkom.no/forskningsetiske-retningslinjer/Samfunnsvitenskap-jus-oghumaniora/a.-forskning-samfunn-og-etikk/

Gudmundsdóttir, S. (2011). Narrativ forskning på pedagogisk praksis. IT. Moen \& R. Karlsdóttir (Red.), Sentrale aspekter ved kvalitativ forskning (s. 45-69). Trondheim: Tapir Akademiske forlag.

Hamre, I. (1997). Marionet og menneske, animationsteater, billedteater: om teaterformens teori og praksis. Gråsten: Drama.

Jewitt, C. (2011). Different approaches to multimodality. I C. Jewitt (Red.), The Routledge Handbook of Multimodal Analysis (s. 28-39). New York: Routledge.

Merleau-Ponty, M. (1968). The visible and the invisible. Followed by working notes. Evanston: Northwestern University Press.

Merleau-Ponty, M. (1994). Kroppens fenomenologi. Oslo: Pax forlag.

Nortvedt, F. (2008). Kroppsfenomenologisk forskning - i grenselandet mellom empiri og filosofi. Vard $i$ Norden, 28(3), 53-55. Hentet 27.04.17 fra http://dx.doi.org/10.1177/010740830802800313

Olaussen, I. (2015). Når leken gir liv. I A. Hammer og G. Strømsøe (Red.), Drama og skapende prosesser $i$ barnehagen (s. 115-130). Bergen: Fagbokforlaget.

Ricoeur, P. (1984). Time and Narrative I (Vol.1) (Oversatt av K. McLaughlin \& D. Pellauver). Chicago: University of Chicago Press.

Østern, T.P. (2017). A forske med kunsten som metodologisk praksis med aesthesis som mandat. Fournal for Research in Arts and Sports Education, Special Issue: «A forske med kunsten «Vol. 1, 2017, s. 7-27. Hentet 17.01.18 fra http://dx.doi.org/10.23865/jased.v1.982 